M. A. Bezmaternikh, I. S. Selezneva

Chemical Technology Institute

28 Mira str., 620002, Ekaterinburg,

E-mail: max6669@rambler.ru

\title{
Milestones chemical technology institute: our past and present
}

The article is devoted to the $95^{\text {th }}$ anniversary of the Chemical technological Institute (CTI) of the Ural Federal University named after the first President of Russia B. N. Yeltsin (UrFU), which will be held in October 2015. Over the years Chemical technological Institute (CTI) has undergone many structure transformations in accordance with the tasks which were set before it the time and the development of our country. Currently this is a fairly large educational and research Institute, which employs more than 100 lecturers including more than 70 associate professors - candidates (PhD), 30 professors - doctors of Sciences $(\mathrm{Hb}), 3$ academics and 1 corresponding member of RAS, trained more than 850 students.

(c) Bezmaternikh M. A., Selezneva I. S., 2015

In October 2015 the Chemical Technology Faculty (CTF) of the Ural Polytechnic Institute named after S. M. Kirov (UPI), and now the Chemical Technology Institute (CTI) of the Ural
Federal University named after the first President of Russia B. N. Yeltsin (UrFU) celebrates its 95th Foundation Anniversary.

\section{Let's remember how it was}

In March 17, 1920 the Chemical Faculty was formed as a result of the division of the Chemical-Metallurgical Faculty of the Ural Mining Institute into separate faculties - chemical and metallurgical. In October 1920 it became part of the Polytechnic Institute, which, along with Mining and other institutions was included in the newly created structure of the Ural State University. In the first academic year in the Chemistry Department were enrolled 145 students.
The first dean of the Faculty was arrived in Ekaterinburg professor of the Petrograd Institute of Technology, electrochemist Alexander Evmenievich Makovetskiy. He can rightly be called the father of the Ural School of chemical engineers. Thanks to the energy A.E. Makovetskiy in the Chemistry Department operated the laboratories for qualitative and quantitative analysis, organic and inorganic chemistry, physical chemistry, dry distillation of wood. And the laboratories were 
available to the students of all faculties and the workers' school. On his initiative in Germany and England were purchased thousands of books and dozens of magazines, which laid a solid Foundation of the scientific library of the Institute.

In February 1922 the chemical and metallurgical faculties again united in the Chemical-Metallurgical Faculty (CMF). The Chemistry Department CMF was training in six specialties, such as "The main chemical productions", "Technology of silicates", "Technological Electrochemistry", "Technology of nonferrous, noble and rare metals," "Pyrogenic processes" and "Pulp and paper industry".

In May 6, 1925 the Ural State University was renamed the Ural Polytechnic Institute.

In June 11, 1929, by the decision of Council of People's Commissars of the RSFSR the chemical branch of the CMF was converted into chemical faculty, the dean of which is approved by Nikolai Rogatkin. In 1929/1930 academic year to the first year of the chemistry Department was taken 220 people.

In 1930 the UPI was transferred under the supervision of the Supreme Council of National Economy, its faculties were transformed into a branch of the technical colleges and for some time have any of the Ural Institute of Chemical Technology (UICT) subordinate to Slavhimprom VSNKh of the USSR.

In the 1930/1931 academic year UICT began work composed of five departments of: the main chemical industry; pyrogenic productions; hardware and design; silicate; engineering and economics.

In May 28, 1934 the branch technical colleges were merged into the Ural Industrial Institute (UII), in its composition on the rights of the faculty of chemical technology entered UICT, and in December 17, 1934 UII was named after S. M. Kirov.

At the beginning of the Great Patriotic War many teachers, researchers and students of the faculty went to the defense of our motherland. The remainder of the team together with the whole country worked under the motto: "All for front, all for victory!" Students and lecturers of the chemistry Department have been created and introduced in manufacture of sulfamide drugs, which contributed to the recovery of the wounded soldiers; developed new catalysts for the flameless combustion of gasoline to use in tactical aircraft to heat engines and cockpit; work on the development and intensification of production of coke and chemical products of coking on the plants of the Urals.

In February 1948 UII was renamed the Ural Polytechnic Institute named after S. M. Kirov.

In December 24, 1992 UPI was renamed the Ural State Technical University (USTU-UPI).

In April 2008, USTU-UPI was named after the first President of Russia B. N. Yeltsin.

In April 2010 the Ural Federal University named after the first President of Russia B. N. Yeltsin was created. In August 30, 2011 on the basis of the Chemical Technology Faculty was established the Chemical Technology Institute.

The leaders of the CTI were N.N. Rogatkin (1927-1929, 19371938), S.G. Mokrushin (1930, 1937), I. G. Shcherbakov (1934-1937), I. Y. Postovsky (1938-1942), A.I. Levin (19421947), Z.V. Pushkareva (1947-1949), V. L. Zolotavin (1949-1951), B. I. Timin (1951-1953), V.M. Cherkasov (1953- 
1958), V. D. Nikitin (1958-1962), B. V. Berezin (1962-1965), A. V. Pomosov (19651974), I. I. Kalinichenko (1974-1982), V. N. Desyatnik (1982-1987), O. N. Chupakhin (1987-1988), A. I. Matern (19882007), from 2008 to present time the Institute is headed by V. L. Rusinov.

Currently at the Institute for $10 \mathrm{de}$ partments work more than 100 teachers, including more than 70 associate professors - candidates of sciences, 30 professors - doctors of sciences, 3 academics and 1 corresponding member of Russian Academy of Sciences, the Institute has about 850 students. The Institute has a wide creative relationships with Ural Branch of Russian Academy of Sciences, a number of industrial enterprises of Sverdlovsk, Orenburg, Chelyabinsk regions, the Perm and Stavropol territory. All Departments are actively engaged in scientific work. More than 40 people are trained in graduate school. For the last five years at CTI protected 4 doctoral and 47 master's theses. In the ranking of hit consistently is in the top among three institutes of the Ural Federal University.

Teachers, postgraduates and students of the faculty work closely with the Catholic University (Leuven, Belgium), KarlAugust University (Germany), with a number of foreign firms. Many teachers, postgraduates and students of the Institute were trained at the Nankai University (Tian-Zhin, China), Howard University (Washington, USA), the University of Maryland (USA), Catholic University (Leuven, Belgium), the University of Geneva (Switzerland), the University of York (UK). Just a 95-year history of the CTI was released 15461 specialists (engineers, bachelors, masters). In addition, faculty of the departments of the Institute provide educational process at the Institutes of Materials Science and Metallurgy (IMSMt), Fundamental Education (InFE), Ural Power Engineering (UralENIN), Physics and Technology (IPT), Mechanical Engineering (IME), Radio electronics and Information Technologies (IRIT-RTF).

\section{Department of Organic \& Biomolecular Chemistry}

From 1924 to 1926 the department was headed by Karmanov S. G., from 1926 to 1976 - by Academician of the RAS Postovsky I. Ya., from 1976 to the present - by Academician of the Russian Academy of Sciences, doctor of chemical sciences Chupakhin O.N.

The department offers two master programs: "Comprehensive chemical and physical study and expert evaluation of organic materials" and "Medical chemistry", one profile bachelor - "Chemical technology of synthetic biologically active substances, pharmaceutical preparations and cosmetics". Scientific directions of the Department belong to different research areas of organic chemistry and organic synthesis, medicinal chemistry, materials science, namely:"Integrated chemical and physical research and expert assessment of organic materials" and "Medical Chemistry", and one bachelor's degree program - "Chemical technology of synthetic biologically active substances, chemical andpharmaceutical preparations and cosmetics."

Research areas of the department belong to different fields of research including organic chemistry and organic synthesis, medicinal chemistry, materials science, namely: 
- nucleophilic aromatic substitution of hydrogen in heteroaromatic and aromatic systems;

- development of methods for the synthesis of heterocycles based on tandem nucleophilic reactions of various types;

- construction of heterocyclic compounds, including those having a fluorine atom in the side chain or the aromatic ring;

- development of methods for the synthesis of fluoroquinolone antibiotics and other inhibitors of DNA gyrase;

- search for substances with antiviral activity;

- synthesis of substances with pharmacological activity, such as anticoagulants, antiplatelet agents, anesthetics, etc.;

- design of anti-tuberculosis drug;

- synthesis of isotope-labeled organic compounds;
- development of methods for preparing substances with a critically high nitrogen content;

- development of methods for the synthesis of effective complexing agents for special purposes;

- development of agents for the extraction of rare earth elements, highly sensitive sensors and fluorescent labels;

- development of highly effective catalytic systems, including systems for asymmetric synthesis.

Over the years, the department graduated 22 doctors and 135 candidates of chemical sciences. Four employees of the department have been elected to the Russian Academy of Sciences - Academicians I. Ya. Postovsky, O. N. Chupakhin, V.N. Charushin and corresponding member of the RAS V. L. Rusinov.

\section{Department of Physical and Colloid Chemistry}

Department of Physical and Colloid Chemistry was founded in 1920. The department was headed by professor Pershke V.K. (1920-1931), docent Zinoviev E.I. (1931-1933), doctor of chemical sciences, professor, Honored worker of science and technology of the RSFSR Mokrushin S. G. (1933-1971), professor, Honored worker of science and technology of the RSFSR Kitaev G. A. (1971-1996), doctor of chemical sciences, professor Makurin Yu.N. (1996-2002), and since 2002 to present time it is headed by professor, Honored worker of higher school Markov V. F.

The department offers 3 master programs: "Technology of materials and products of optoelectronics and sensorics", "Physicochemical technologies of crystals and infrared optical fibers", "Chemical thin-film technologies in optoelectronics and nanoelectronics", and one bachelor's degree program - "Physicochemical technologies of materials of electronic technology and power industry".

Academics, graduate and undergraduate students of the department are engaged in scientific research in the following areas:

- quantum chemical modeling of the structure, functional properties and reactivity of molecules;

- development of technology of hydrochemical synthesis of thin films of dielectric, semiconductor and metal materials;

- development of new, including nanostructured, sensor materials for infrared technology and chemical analysis;

- study and development of new fiber materials, scintillators, and based on them creation of optical fibers for infrared region of the spectrum; 
- synthesis and study of properties of new X-ray contrast agents for medicine.
The department has trained more than 90 candidates and 6 doctors of sciences.

\section{Department of Technology of Inorganic Substances}

Department of Technology of inorganic substances was founded in 1920. The department was headed by professor Yushkevich N. F. (1921-1923), professor Makovetskiy A.E. (1923-1929), professor Shabalin K. N. (1929-1937), professor Kuz'minykh I.N. (1937-1943), professor Vilnyansky Ya.E. (1943-1973), docent Chukhlantsev V.G. (1973-1978), professor Desyatnik V.N. (1978-2001), professor Trifonov K. I. (1997-1999), and since 2001 to present time it is headed by professor Katishev S. F.

The department implements the master program "Chemical Technology of basic inorganic synthesis" and the bachelor's degree program "Chemical technology of inorganic substances”.
Scientific fields of the department are:

- physical chemistry and technology of melts containing rare earth elements;

- development of methods of physicochemical analysis of ionic equilibria in complex composition solutions;

- physicochemical basis of preparation of magnesium chloride feed to electrolysis;

- effective ways of using waste products of hydrofluoric and phosphoric acids and fluorides;

- development and simulation of technologies for processing man-made structures.

To date the department has trained 2 Academicians, 4 laureates of the State Prize, 5 doctors and 50 candidates of sciences.

\section{Department of processes and apparatus of chemical technology}

Department of processes and apparatus of chemical technology was established in 1920. The department was headed by professor Makovetskiy A. E. (1920-1932), professor Plyusnin V.G. (1932-1936), professor Shabalin K. N. (1936-1966), professor Zaostrovsky F.P. (1967-1991), professor Pospelov F. M. (1992-1995), professor Ermakov A.A. (1995-2010), and since 2011 to present time it is headed by professor Ermakov S. A.
The department trains bachelors in the profile "Basic processes of chemical production and chemical cybernetics".

Academics, staff, graduate and undergraduate students of the department are involved in fundamental and applied research in two areas:

- intensifying the mass and heat transfer under conditions of hydrodynamic instability of the phases contact surface in liquid-liquid systems;

- hydrodynamic separation of heterogeneous gas systems.

\section{Department of Technology of Electrochemical Production}

Department of Technology of Electrochemical Production was founded in 1923. The department was headed by professor Shcherbakov I. G. (1923-1938), professor Esin O.A. (1938-1944), professor Levin A.I. (1944-1978), professor Pomosov A.V. (1978-1988), professor Rudoi V.M. (1988-1998), professor 
Samoilenko V. N (1998-2000), and since 2000 to present time it is headed by professor Zaykov Yu. P.

Currently, the department offers one bachelor's degree program: “Technology of electrochemical productions", master programs: "Electrochemical processes and productions", "Hydrogen and electrochemical power industry", "Technology of chemical and electrochemical materials protection".

The cooperation of the department with factories of OJSC "Gazprom" has resulted in the opening a new form of specialists education which is applied bachelor's program.

The main scientific fields of the department are basic research in the field of electrodeposition and electrocrystallization of metals, protection against materials corrosion, production of current sources:

- model description of electrocrystallization of metals in the form of dendrites;

- electrolysis in nonferrous metallurgy;

- electrolytic molding of gold and silver articles;

- study of corrosion protective properties of paint coatings and protective alloys;

- improvition manufacturing processes and electrical characteristics of a lead accumulator.

More than 40 graduates of the department became doctors of sciences and 170 are candidates of sciences.

\section{Department of chemical technology of fuel and industrial ecology}

Department of chemical technology of fuel and industrial ecology was founded in 1923.

The department was headed by professor Rogatkin N. N. (1923-1944), professor Syskov K. I. (1944-1947), professor Goftman M.V. (1947-1967), professor Kharlampovich G.D. (1967-1997), docent Shishov M.G. (1997-2008), and since 2008 to present time it is headed by docent Stakheev S. G.

Currently, the department offers the following bachelor's degree programs: "Chemical technology of natural energy resources" and "Environmental protection and rational use of natural resources", as well as the following master programs:
"Chemical technology of natural energy resources and carbon materials" and "Industrial ecology and rational use of natural resources".

The main scientific fields of the department are:

- optimization of processes of coal processing and products produced from them in different pyrogenetic processes;

- environmental impact assessment of projects and the development of environmental design documentation.

22 graduates of the department became doctors of sciences and 130 are candidates of technical and chemical sciences.

\section{Department of Machines and Apparatus for Chemical Productions}

Department of Machines and Apparatus for Chemical Productions was organized in 1932. The department was headed by professor Dal'-Chumachenko V.I.
(1932-1941), professor Shabalin K.N. (1941-1960), professor Volgin B.P. (1960-1977), Berezin B. V. (1977-1982), docent Yugay F.S. (1982-1996), profes- 
sor Chernomurov F. M. (1996-2006), and since 2006 to present time it is headed by professor Khomyakov A. P.

Today, the undergraduate training is implemented on the bachelor's degree programs «Machines and apparatus for chemical productions", "Machines and apparatus for food production," and on master's degree program "Machines and apparatus for chemical productions".

The main scientific research fields of the department relate to:

- development of heat and mass transfer apparatus based on the Venturi tube;

- implementation of high-speed spray type apparatus for the treatment of process gases in a variety of productions;

- removal of harmful impurities, cooling, absorption;

- development of systems of gas purification from dust, mist, vapor, based on ejection type scrubbers;

- modernization of evaporation and heat exchange equipment, boiler deaerators;

\section{Department of Analytical Chemistry}

Department of Analytical Chemistry was founded in 1933. The department was headed by docent Levin A. B. (19331938), professor Tananaev N.A. (19381959), professor Podchaynova V.N. (1960-1977), professor Polezhaev Yu.M. (1977-2000), since 2000 to present time it is headed by professor Matern A. I.

The department offers two master programs "Electrochemical methods and sensors for environmental and biological objects monitoring", "Instrumental methods of research in the pharmaceutical industry". From 2015 the department offers one bachelor's degree program: "Instru-
- study of wear of parts of hydraulic machines at cavitation and hydroabrasive impact;

- development of apparatus in the field of resource and energy saving technologies;

- use of hydrodynamic cavitation systems for dissipative heating; homogenizing and pasteurizing liquids for food and industrial use;

- applying the principle of evaporation-condensation heat exchange to create technological and power equipment, utilization of secondary energy resources;

- development and implementation of energy technological complexes, providing the ultimate closure of material and energy flows within the unit, department, factory;

- investigation of processes and development of equipment for the food industry.

The department has prepared 13 laureates of Lenin and State Prizes of the USSR Council of Ministers Prize, 7 doctors of sciences, 107 candidates of sciences.

mental methods of analysis of natural and technical objects".

Currently, the department of analytical chemistry of the CTI conducts active scientific research. Main research fields are:

- development of sensors, instruments and automated electrochemical complex for environmental monitoring of heavy metals in online mode;

- studies of antioxidant and anti-radical activity of solutions;

- non-enzymatic methods for determining diagnostically significant parameters;

- development of methods for electrochemical immunoassay; 
- study of the toxicity of nanoparticles;

- study of mechanisms electro-transformations of organic compounds and pharmaceuticals;
- definition of basic substance and impurities in pharmaceuticals.

\section{Department of Technology for Organic Synthesis}

Department of Technology for Organic Synthesis was established in 1947. Department was headed by professor, Honored worker of science and technology of the RSFSR Pushkareva Z.V. (1947-1982), professor Shishkina V.I. (1982-1988), professor Mokrushin V.S. (1988-2008), from 2008 to present time it is headed by professor Bakoulev V. A.

The department of TOS offers bachelors 3 bachelor's degree programs: "Chemical technology of organic substances", "Biotechnology" and "Food biotechnology". 6 master's programs are implemented: "Chemical technology of fine organic synthesis", "Chemical technology of biologically active substances", "Chemical technology of basic organic and petrochemical synthesis», "Chemical technology of plastics," "Medical biotechnology",

\section{Department of Immunochemistry}

Department of Immunochemistry was founded in 2000 on the initiative and with the participation of Academician Chereshnev V.A., who heads the department from the first days of creation and to present time.

The department offers master program "Immunobiotechnology."

Scientific activity of the department is connected with the research in the field of biochemistry and immunochemistry. One of the research fields is the study of non-enzymatic protein glycosylation reaction that underlies the pathogenesis of many social diseases. The second field
"Food biotechnology" (in Russian and English).

The main research fields of the department are:

- fine organic synthesis in the field of heterocyclic and natural compounds;

- creation of new advanced materials;

- development of new and improvement of the known technological processes;

- nanotechnologies based on organic compounds;

- medical, food and environmental biotechnology.

Among the graduates and staff of the department 370 people defended their candidate's dissertations, 40 - doctoral dissertations, 20 graduates received the State Prize, 15 became heads of departments of various universities.

is the study of mechanisms of cytokine regulation of physiological processes in blood cells and vascular walls in hyperglycemia. This work is done in collaboration with the Institute of Immunology of the Russian Academy of Sciences.

Currently, the Chemical Technology Institute offers three directions for undergraduate students: "Biotechnology", "Chemical technology", "Energy and resource saving processes in chemical technology, petrochemistry and biotechnology", as well as offers the same directions and the direction "Chemistry" for masters. The Institute implements 12 individ- 
ual bachelor's degree programs within the undergraduate education and 24 master programs, including one in English.

In 2008, the educational program "Technology of electrochemical production" (TECP) passed the procedure of public and professional accreditation of the Association of Engineering Education of Russia. Specialization TECP is the only specialization in the Urals region, which is assigned a European quality mark EUR$\mathrm{ACE}^{\circledast}$.

In June 2012 the basic education program "Biotechnology" passed the procedure of public and professional accreditation of the Public Accreditation Agency for Higher Education Quality Assurance and Career Development and confirmed the conformity of the quality of training of graduates of the program to quality standards and quality assurance, established on the basis of the recommendations of the European Association for Quality Assurance in Higher education.

In addition to academic work lecturers and staff are actively engaged in scientific research. Due to the internationalization the research received a powerful impetus for development. The number of articles and books published in international journals in English has been increased. Original chemical compounds with biological activity have been synthesized. Students under the guidance of lecturers are actively involved in implementation of sophisticated chemical experiments. Foreign scientists from leading universities around the world often come to the Institute to delivery lectures to staff and students. On the other hand, our undergraduate and graduate students regularly travel abroad (Australia, Austria, England, Belgium, Germany, China, USA and Japan) for undertaking scientific internships. There they can get a new experience, gain new knowledge and improve spoken English. Our staff and graduate students often win grants for the implementation of scientific research and participation in Russian and international conferences.

In conclusion we would like to congratulate all the academics, staff, students and graduates of the Chemical Technology Institute with the upcoming anniversary! We wish you all success and new victories! We love CTI! We wish CTI all the best! 
М. А. Безматерных, И. С. Селезнева

Химико-технологический институт 620002 Екатеринбург, ул. Мира, 28.

E-mail:max6669@rambler.ru

\section{Этапы большого пути: наше прошлое и настоящее}

Статья посвящена 95-летнему юбилею Химико-технологического института (ХТИ) Уральского федерального университета имени первого Президента России Б. Н. Ельцина (УрФУ), который состоится в октябре 2015 года. За эти годы Химико-технологический институт (ХТИ) претерпел множество структурных преобразований в соответствии с задачами, которые ставили время и развитие нашей страны. В настоящее время это достаточно большой учебный и исследовательский институт, в котором работают более 100 преподавателей, из них свыше 70 доцентов - кандидатов наук, 30 профессоров докторов наук, 3 академика и 1 член-корреспондент РАН, обучаются более 850 студентов.

(c) Безматерных М. А., Селезнева И. С., 2015

В октябре 2015 года исполняется 95 лет химико-технологическому факультету (ХТФ), Уральского политехнического института имени С. М. Кирова (УПИ), а ныне - Химико- технологическому институту (ХТИ) Уральского федерального университета имени первого Президента России Б. Н. Ельцина (УрФУ).

\section{Вспомним, как это было}

17 марта 1920 года образовался химический факультет в результате разделения химико-металлургического факультета Уральского горного института на отдельные факультеты - химический и металлургический. В октябре 1920 года он вошел в состав Политехнического института, который наряду с Горным и другими институтами был включен в структуру вновь созданного Уральского госуниверситета.
В первом учебном году на химфаке обучалось 145 студентов.

Первым деканом факультета стал приехавший в Екатеринбург профессор Петроградского технологического института, электрохимик Александр Евменьевич Маковецкий. Его по праву можно назвать отцом уральской школы инженеров-химиков. Благодаря энергии А. Е. Маковецкого на химфаке действовали лаборатории качествен- 
ного и количественного анализа, органической и неорганической химии, физической химии, сухой перегонки дерева. Причем лаборатории были доступны для студентов всех факультетов и рабфака. По его инициативе в Германии и Англии были закуплены тысячи книг и десятки журналов, заложивших солидную основу научной библиотеки института.

В феврале 1922 года химический и металлургический факультеты снова объединены в химико-металлургический факультет (ХМФ). На химическом отделении ХМФ осуществлялась подготовка специалистов по шести специальностям: «Основные химические производства», «Технология силикатов», «Технологическая электрохимия», «Технология цветных, благородных и редких металлов», «Пирогенные процессы» и «Целлюлозно-бумажное производство».

6 мая 1925 года Уральский государственный университет был переименован в Уральский политехнический институт.

11 июня 1929 года решением СНК РСФСР химическое отделение ХМФ преобразовано в химический факультет, деканом которого утвержден Николай Николаевич Рогаткин. В 1929/1930 учебном году на первый курс химфака было принято 220 человек.

В 1930 году УПИ был передан в ведение ВСНХ, его факультеты преобразованы в отраслевые втузы, и на некоторое время возник Уральский химико-технологический институт (УХТИ), подчиненный Главхимпрому ВСНХ СССР.

В 1930/1931 учебном году УХТИ начал работу в составе пяти отделений: основной химической промышленно- сти; пирогенных производств; аппаратурно-конструкторского; силикатного; инженерно-экономического.

28 мая 1934 году отраслевые втузы были объединены в Уральский индустриальный институт (УИИ), в его состав на правах химико-технологического факультета вошел УХТИ, а 17 декабря 1934 года УИИ было присвоено имя С. М. Кирова.

В начале Великой Отечественной войны многие преподаватели, научные работники и студенты факультета ушли на защиту нашей Родины. Оставшаяся часть коллектива вместе со всей страной трудилась под девизом: «Все для фронта, все для победы!» Преподавателями и учеными химфака были созданы и внедрены в производство сульфамидные препараты, которые способствовали выздоровлению раненых воинов; разработаны новые катализаторы для беспламенного горения бензина с целью применения во фронтовой авиации для обогрева моторов и кабин самолетов; проведена работа по развитию и интенсификации производства кокса и химических продуктов коксования на заводах Урала.

В феврале 1948 года УИИ был переименован в Уральский политехнический институт имени С. М. Кирова.

24 декабря 1992 года УПИ переименован в Уральский государственный технический университет (УГТУ-УПИ).

В апреле 2008 года УГТУ-УПИ присвоено имя первого Президента России Б. Н. Ельцина.

В настоящее время в институте на 10 кафедрах работают более 100 преподавателей, из них свыше 70 доцентов - кандидатов наук, 30 профессоров - докторов наук, 3 академика 
и 1 член-корреспондент РАН, обучаются около 850 студентов. Институт имеет широкие творческие связи с УрО РАН, целым рядом промышленных предприятий Свердловской, Оренбургской, Челябинской областей, Пермского и Ставропольского края. Все кафедры активно ведут научную работу. Более 40 человек обучаются в аспирантуре. За пять последних лет на ХТИ защищено 4 докторских и 47 кандидатских диссертаций. В общеуниверситетском рейтинге ХТИ стабильно входит в тройку лучших институтов УрФУ.

Преподаватели, аспиранты и студенты факультета тесно взаимодействует с Католическим университетом (г. Левен, Бельгия), Карл-Август Университетом (Германия), с целым рядом зарубежных фирм. Многие преподаватели, аспиранты и студенты ХТИ

\section{Кафедра органической химии}

С 1924 по 1926 год кафедру возглавлял С. Г. Карманов, с 1926 по 1976 год академик РАН И.Я. Постовский, с 1976 года по настоящее время - академик РАН, доктор химических наук О. Н. Чупахин.

На кафедре реализуется подготовка по двум магистерским программам: «Комплексное химическое и физическое исследование и экспертная оценка органических материалов» и «Медицинская химия», по одному профилю бакалавриата - «Химическая технология синтетических биологически активных веществ, химико-фармацевтических препаратов и косметических средств».

Научные направления кафедры относятся к разным областям исследова- прошли стажировку в Нанкайском университете (г. Тянь-Жинь, Китай), Хавардском университете (г. Вашингтон, США), университете г. Мэриленд (США), Католическом университете (г. Левен, Бельгия), Женевском университете (Швейцария), Йоркском университете (Великобритания).

Всего за 95-летнию историю ХТИ было выпущено 15461 специалист (инженеров, бакалавров, магистров). Кроме того, преподаватели кафедр ХТИ осуществляют образовательный процесс в Институтах материаловедения и металлургии (ИМиМт), Фундаментального образования (ИнФО), Уральском энергетическом (УралЭНИН), Физико-технологическом (ФТИ), Механико-машиностроительном (ММИ), Радиоэлектроники и информационных технологий (ИРИТ-РТФ).

ний - органической химии и органического синтеза, лекарственной химии, материаловедения, а именно:

- ароматическое нуклеофильное замещение водорода в гетероароматических и ароматических системах;

- создание методов синтеза гетероциклов, основанных на тандемных нуклеофильных реакциях различного типа;

- конструирование гетероциклических соединений, в том числе имеющих атомы фтора в боковой цепи или ароматическом ядре;

- разработка методов синтеза антибиотиков фторхинолонового ряда и других ингибиторов ДНК-гиразы;

- поиск веществ, обладающих противовирусной активностью; 
- синтез веществ, обладающих фармакологической активностью - антикоагулянтов, антиагрегантов, анестетиков и др.;

- создание противотуберкулезных препаратов;

- синтез изотопно-меченых органических соединений;

- разработка методов получения веществ с критически высоким содержанием азота;

- развитие способов синтеза эффективных комплексообразователей специального назначения,
- создание экстрагентов редкоземельных элементов, высокочувствительных сенсоров и люминесцентных меток;

- создание высокоэффективных каталитических систем, в том числе для асимметрического синтеза.

За годы существования кафедрой подготовлено 22 доктора и 135 кандидатов химических наук. Четыре сотрудника кафедры избраны членами РАН - академики И.Я. Постовский, О.Н. Чупахин, В.Н. Чарушин и членкорреспондент РАН В. Л. Русинов.

\section{Кафедра физической и коллоидной химии}

Кафедра физической и коллоидной химии основана в 1920 году. Кафедру возглавляли профессор В.К. Першке (1920-1931), доцент Е.И. Зиновьев (1931-1933), д. х. н., профессор, заслуженный деятель науки и техники РСФСР С.Г. Мокрушин (1933-1971), д. х. н., профессор, заслуженный деятель науки и техники РСФСР Г. А. Китаев (1971-1996), д. х. н., профессор Ю. Н. Макурин (1996-2002), а с 2002 г. д.х. н., профессор, почетный работник высшей школы В.Ф. Марков.

На кафедре открыты три магистерские программы: «Технологии материалов и изделий оптоэлектроники и сенсорики», «Физико-химические технологии кристаллов и ИК-световодов», «Химические тонкопленочные технологии в оптоэлектронике и наноэлектронике» и один профиль бакалавриата - «Физико-химические технологии материалов электронной техники и энергетики».
Преподаватели, аспиранты и студенты кафедры занимаются научной работой по следующим направлениям:

- квантово-химическое моделирование структуры, функциональных свойств и реакционной способности молекул;

- разработка технологии гидрохимического синтеза тонких пленок диэлектрических, полупроводниковых и металлических материалов;

- разработка новых, в том числе наноструктурированных, сенсорных материалов для инфракрасной техники и химического анализа;

- исследование и разработка новых волоконных материалов, сцинтилляторов и создание на их основе световодов для ИК-области спектра;

- синтез и исследование свойств новых рентгеноконтрастных веществ для медицины.

Кафедрой подготовлено более 90 кандидатов и 6 докторов наук. 


\section{Кафедра технологии неорганических веществ}

Кафедра технологии неорганических веществ основана в 1920 году. Заведующими кафедрой были профессор А. Е. Маковецкий (1923-1929), профессор Н.Ф. Юшкевич (1921-1923), профессор К.Н. Шабалин (1929-1937), профессор И.Н. Кузьминых (19371943), профессор Я.Е. Вильнянский (1943-1973), доцент В.Г. Чухланцев (1973-1978), профессор В. Н. Десятник (1978-2001), профессор К.И. Трифонов (1997-1999), с 2001 г. - профессор С. Ф. Катышев.

На кафедре реализуется магистерская программа «Химическая технология основного неорганического синтеза» и профиль бакалавриата «Химическая технология неорганических веществ».

К научным направлениям кафедры относятся:
- физическая химия и технология расплавов, содержащих редкоземельные элементы;

- разработка методов физико-химического анализа ионных равновесий в растворах сложного состава;

- физико-химические основы подготовки хлормагниевого сырья к электролизу;

- эффективные направления использования отходов производства фтороводородной и фосфорной кислот и фтористых солей;

- разработка и моделирование технологий переработки техногенных образований.

На сегодняшний день кафедра подготовила 2 академиков, 4 лауреатов Государственной премии, 5 докторов наук и более 50 кандидатов наук.

\section{Кафедра процессов и аппаратов химической технологии}

Кафедра процессов и аппаратов химической технологии организована в 1920 году. Кафедрой заведовали профессор А. Е. Маковецкий (1920-1932), профессор В. Г. Плюснин (1932-1936), профессор К.Н. Шабалин (1936-1966), профессор Ф.П. Заостровский (19671991), профессор Ф.М. Поспелов (1992-1995), профессор А.А. Ермаков (1995-2010), с 2011 года - профессор С. А. Ермаков.

Кафедра готовит бакалавров по профилю «Основные процессы хими- ческих производств и химическая кибернетика».

Преподаватели, сотрудники, аспиранты и студенты кафедры проводят фундаментальные и прикладные исследования по двум направлениям:

- интенсификация массо- и теплообмена в условиях гидродинамической неустойчивости поверхности контакта фаз в системах жидкость-жидкость;

- гидродинамическое разделение неоднородных газовых систем.

\section{Кафедра технологии электрохимических производств}

Кафедра технологии электрохимических производств основана в 1923 году. Кафедру возглавляли профессор И. Г. Щербаков (1923-1938), профес- сор О. А. Есин (1938-1944), профессор А.И. Левин (1944-1978), профессор А. В. Помосов (1978-1988), профессор В. М. Рудой (1988-1998), профессор 
В.Н. Самойленко (1998-2000), с 2000 года - профессор Ю. П. Зайков.

В настоящее время кафедра готовит бакалавров по профилю «Технология электрохимических производств», магистрантов по программам «Электрохимические процессы и производства», «Водородная и электрохимическая энергетика», «Технология химической и электрохимической защиты материалов».

Результатом взаимодействия кафедры с предприятиями ОАО «Газпром» стало открытие новой формы обучения специалистов прикладного бакалавриата.

Основными научными направлениями кафедры являются фундаментальные исследования в области электро-

осаждения и электрокристаллизации металлов, защиты от коррозии материалов, производства источников тока:

- модельное описание электрокристаллизации металлов в виде дендритов;

- электролиз в цветной металлургии;

- электролитическое формование изделий из золота и серебра;

- исследование коррозионно-защитных свойств лакокрасочных покрытий и протекторных сплавов;

- совершенствование технологических процессов производства и электрических характеристик свинцового аккумулятора.

Более 40 выпускников кафедры стали докторами наук и 170 - кандидатами наук.

\section{Кафедра химической технологии топлива и промышленной экологии}

Кафедра химической технологии топлива и промышленной экологии основана в 1923 году.

Кафедру возглавляли профессор Н. Н. Рогаткин (1923-1944), профессор К. И. Сысков (1944-1947), профессор М. В. Гофтман (1947-1967), профессор Г. Д. Харлампович (1967-1997), доцент М. Г. Шишов (1997-2008), с 2008 года доцент С. Г. Стахеев.

В настоящее время кафедра готовит бакалавров по профилям «Химическая технология природных энергоносителей» и «Охрана окружающей среды и рациональное использование природных ресурсов», а также магистрантов по программам «Химическая технология природных энергоносителей и углеродных материалов» и «Промышленная экология и рациональное использование природных ресурсов».

Основными научными направлениями работы кафедры являются:

- оптимизация процессов переработки углей и получаемых из них при различных пирогенетических процессах продуктов;

- экологическая экспертиза проектов и разработка экологической проектной документации.

22 выпускника кафедры стали докторами наук и 130 - кандидатами технических и химических наук.

\section{Кафедра машин и аппаратов химических производств}

Кафедра машин и аппаратов химических производств организована в 1932 году. Кафедру возглавля- ли профессор В.И. Даль-Чумаченко (1932-1941), профессор К. Н. Шабалин (1941-1960), профессор Б. П. Волгин 
(1960-1977), Б. В. Березин (1977-1982), доцент Ф.С. Югай (1982-1996), профессор Ф. М. Черномуров (1996-2006), с 2006 года - профессор А. П. Хомяков.

Сегодня обучение в рамках бакалавриата ведется по профилям «Машины и аппараты химических производств», «Машины и аппараты пищевых производств» и в магистратуре по программе ««Машины и аппараты химических производств».

К основным научным направлениям деятельности кафедры относятся:

- разработка тепло- и массообменных аппаратов на основе трубы Вентури;

- внедрение скоростных аппаратов распыляющего типа для обработки технологических газов в различных производствах;

- очистка от вредных примесей, охлаждение, абсорбция;

- разработка систем очистки газов от пыли, тумана, паров на основе скрубберов эжекционного типа;

- модернизация выпарного и теплообменного оборудования, котельных деаэраторов;

- исследования изнашивания деталей гидравлических машин при ка-

\section{Кафедра аналитической химии}

Кафедра аналитической химии основана в 1933 году. Кафедрой заведовали доцент А. Б. Левин (1933-1938), профессор Н. А. Тананаев (1938-1959), профессор В.Н. Подчайнова (19601977), профессор Ю.М. Полежаев (1977-2000), с 2000 года - профессор А. И. Матерн.

На кафедре ведется подготовка магистрантов по двум программам «Электрохимические методы и сенсо- витационном и гидроабразивном воздействии;

- разработка аппаратов в области ресурсо- и энергосберегающих технологий;

- применение гидродинамических кавитационных установок для диссипативного нагрева; гомогенизации и пастеризации жидких сред пищевого и технического назначения;

- применение принципа испарительно-конденсационного теплообмена для создания технологического и теплоэнергетического оборудования, утилизации вторичных энергоносителей;

- разработка и внедрение энерготехнологических комплексов, обеспечивающих предельную замкнутость материальных и энергетических потоков в рамках агрегата, цеха, предприятия;

- исследование процессов и разработка аппаратуры для пищевых производств.

Кафедрой подготовлено 13 лауреатов Ленинской и Государственной премий СССР, премии Совета Министров, 7 докторов наук, 107 кандидатов наук.

ры для мониторинга окружающей среды и биологических объектов», «Инструментальные методы исследования в фармацевтике». В 2015 году кафедра открыла бакалавриат по профилю «Инструментальные методы анализа природных и технических объектов».

В настоящее время кафедра аналитической химии ХТИ ведет активную научную работу. Основные направления исследований: 
- разработка сенсоров, приборов и автоматического электрохимического комплекса для экомониторинга тяжелых металлов в online-режиме;

- исследования антиоксидантной и антирадикальной активности растворов;

- бесферментные методы определения диагностически значимых параметров;

\section{Кафедра технологии органического синтеза}

Кафедра технологии органического синтеза (ТОС) организована в 1947 году. Кафедрой заведовали профессор, заслуженный деятель науки и техники РСФСР З. В. Пушкарева (1947-1982), профессор В. И. Шишкина (1982-1988), профессор В.С. Мокрушин (19882008), с 2008 года по настоящее время профессор В. А. Бакулев.

Кафедра ТОС выпускает бакалавров по трем профилям: «Химическая технология органических веществ», «Биотехнология» и «Пищевая биотехнология». Реализуются шесть магистерских программ: «Химическая технология тонкого органического синтеза», «Химическая технология биологически активных веществ», «Химическая технология основного органического и нефтехимического синтеза», «Химическая технология пластических масс», «Медицинская биотехнология», «Пищевая биотехязыках). вузов.
- разработка методов электрохимического иммуноанализа;

- исследование токсичности наночастиц;

- исследование механизмов электропревращений органических соединений и фармпрепаратов;

- определения основного вещества и примесей в фармпрепаратах.

нология» (на русском и английском

Основными научными направлениями кафедры являются:

- тонкий органический синтез в области гетероциклических и природных соединений;

- создание новых перспективных материалов;

- разработка новых и совершенствование известных технологических процессов;

- нанотехнологии на основе органических соединений;

- медицинская, пищевая и экобиотехнология.

Из числа выпускников и сотрудников кафедры 370 человек защитили кандидатские диссертации, 40 - докторские, 20 выпускников стали лауреатами Государственной премии, 15 заведующими кафедрами различных

\section{Кафедра иммунохимии}

Кафедра иммунохимии основана в 2000 году по инициативе и при участии академика РАН В.А. Черешнева, который с первых дней создания и по настоящее время возглавляет кафедру.

Кафедра ведет подготовку магистрантов по программе «Иммунобиотехнология».

Научная деятельность кафедры связана с исследованиями в области биохимии и иммунохимии. Одним из 
научных направлений является изучение реакции неферментативного гликозилирования белков, которая лежит в основе патогенеза многих социально значимых заболеваний. Второе направление - исследование механизмов цитокининовой регуляции физиологических процессов в клетках крови и сосудистой стенки в условиях гипергликемии. Эта работа выполняется совместно с Институтом иммунологии PAH.

В настоящее время в Химико-технологическом институте ведется подготовка бакалавров по трем направлениям: «Биотехнология», «Химическая технология», «Энерго- и ресурсосберегающие процессы в химической технологии, нефтехимии и биотехнологии», а также магистрантов по этим же направлениям и по направлению «Химия». В рамках бакалавриата реализуется подготовка по 12 индивидуальным траекториям (профилям) и в магистратуре открыто 24 магистерские программы, в том числе одна на английском языке.

В 2008 году образовательная программа «Технология электрохимических производств» прошла процедуру общественно-профессиональной аккредитации Ассоциации инженерного образования России. Специальность ТЭХП - единственная специальность в Уральском регионе, которой присвоен европейский знак качества EUR$\mathrm{ACE}^{\circledast}$.

В июне 2012 года основная образовательная программа «Биотехнология» прошла общественно-профессиональную аккредитацию Агентства по общественному контролю качества образования и развитию карьеры и подтвердила соответствие качества подготовки выпускников программы Стандартам качества и гарантий качества, установленным на основании рекомендаций Европейской ассоциации гарантий качества в высшем образовании.

Помимо учебной работы, преподаватели и сотрудники кафедр активно занимаются научными исследованиями. Благодаря интернационализации научные исследования получили мощный импульс к развитию. Увеличилось количество статей и монографий, опубликованных в международных журналах на английском языке. Синтезированы оригинальные химические соединения с биологической активностью. Студенты под руководством преподавателей активно участвуют в выполнении сложных химических экспериментов. К нам часто приезжают иностранные ученые из ведущих университетов мира для чтения лекций сотрудникам кафедры и студентам. С другой стороны, наши студенты и аспиранты регулярно выезжают за рубеж (Австралия, Австрия, Англия, Бельгия, Германия, Китай, США и Япония) для прохождения научных стажировок за рубежом. Там они приобретают новый жизненный опыт, получают новые знания и совершенствуют разговорный английский язык. Наши сотрудники и аспиранты часто выигрывают гранты на выполнение научных работ и для участия в российских и международных конференциях.

В заключение хочется поздравить всех преподавателей, сотрудников, студентов и выпускников химико-техно- 
логического института с предстоящим юбилеем! Желаем всем творческих успехов и новых побед! Мы любим тебя, ХТИ! Живи, процветай и крепни! 